\title{
Sciendo
}

DOI 10.2478/afepuc-2021-0016

(C) 2021 Author(s). This is an open access article licensed under the Creative Commons

Attribution-NonCommercial-NoDerivatives 4.0 International

(https://creativecommons.org/licenses/by-nc-nd/4.0/)

\section{PHYSIOLOGICAL RESPONSE OF THE PERFORMANCE OF YOUNG FOOTBALL PLAYERS DURING SMALL-SIDED GAMES}

\author{
Nikolas Nagy ${ }^{1}$, Miroslav Holienka ${ }^{1}$, Matej Babic ${ }^{2}$ \\ ${ }^{1}$ Department of Sports Games, Faculty of Physical Education and Sports, Comenius University in Bratislava, \\ Slovakia \\ ${ }^{2}$ Department of Physical Education and Sports, Faculty of Chemical and Food Technology, Slovak University \\ of Technology in Bratislava, Slovakia
}

\begin{abstract}
Summary: The main aim of the present study was to examine the cardiovascular response, time-motion characteristics, game performance and rated of perceived exertion (RPE) during small-sided games (SSGs) with different number of players. The research group consisted of elite youth male soccer players $(\mathrm{n}=18)$ (aged $16.5 \pm 0.71$ years, maximum heart rate $\left(\mathrm{HR}_{\max }\right) 196.42 \pm 5.31$ beats. $\left.\mathrm{min}^{-1}\right)$ from the FC DAC 1904 Dunajská Streda U17 soccer club. Cardiovascular response measurements included heart rate (HR) expressed in minimum, mean and maximum values and time spent in different intensity zones. Total distance covered, high intensity running and the number of accelerations and decelerations were captured by GPS. Individual game performance and the number of technical-tactical actions were recorded during every SSGs. After the game time we collected the ratingsof perceived exertion scores from each player. Results showed that SSG with small number of players (3 vs. 3) triggered the highest HR response with mean value $168.00 \pm 8.48$ beats. $\mathrm{min}^{-1}$, players spent the most time in maximal intensity zone 0:09:06 minutes, of SSG duration. This format of SSG was the mostintensefor the players' cardiovascular system, but we can't find statistically significant differences between the HR values in SSGs. External load was the most demanding in SSG1 too, like in internal load. The highest scores in individual game performance were recorded in SSG2. In RPE scores SSG1 was the most difficult from the players point of view. In conclusion, the present research demonstrates the effectiveness of SSG1 in training sessions. Therefore, the coaching staff has the possibility to choose between SSGs during training sessions according to their physical, technical, tactical and psychological objectives.
\end{abstract}


Key Words: soccer, small-sided games, internal load, time-motion characteristics, individual game performance, RPE

\section{Introduction}

The purpose of thoughtful training process is to help increase the adaptation capacity of player's organism to the load, with which players are frequently confronted during competitive soccer match. The systematic training process should prepare players for game demands in technical, tactical, physiological and psychological way.

Holienka (1998) claims that the current fundamental principle in well-thought soccer training process - all with a ball - fulfils the game training. Small-sided games (SSGs) play an essential part in the training process, which contain a lot of different game situation that are very similar to the real game situations during a match. Ideally, the training process has to contain SSGs, where the soccer players physiological curve moves at the level or above of the anaerobic threshold (ANT).

Different forms of SSGs are widely used in soccer practice (Clemente et al. 2012). SSGs allow the players to gain valuable soccer experience, because they have to deal with the game situations, which often occur during matches. When solving the various complex game situations during SSGs, players are able to improve their technical ability, tactical behaviour, fitness aspect of their game preparedness and their mental resistance as well.

Kačáni (2004) divides the SSGs according to the number of players into 3 groups: 1. group $=$ SSG - small (from 1 to 3 players). During small forms of SSGs (1 vs. 1 to 3 vs. 3 ) the training load often higher than the real soccer match intensity.

2. group $=$ SSG - medium (from 4 to 6 players). During medium forms of SSGs (4 vs. 4 to 6 vs. 6 ) the training load is at the same level of intensity as during the most intense periods of soccer matches.

3. group $=$ SSG - large (from 7 to 9 players). During large forms of SSGs (7 vs. 7 to 9 vs. 9) the load in LSG at the same level like during the competitive matches.

SSGs involve a smaller number of players, play on reduced field area and often use modified rules not like traditional competitive soccer match. Therefore, these types of exercises, which induce greater heterogeneous response than traditional fitness training methods, are very popular and useful training drills for players of all ages and playing levels especially with younger age groups (Dellal et al. 2011).

Nowadays, previous studies have examined that soccer coaches can influence the intensity of training load in SSGs if they adequately change the variables, which are affecting 
the intensity of SSGs. The variables include: the number of participating players, size of the game field, coach encouragement, presence of goalkeepers, size of the goal, number of goals, game rules, work interval and rest interval too (Owen et al. 2004; Rampinini et al. 2007; HillHaas et al. 2011; Köklü et al. 2013; Mikulič et al. 2018; Nagy a Holienka 2018; Peráček et al. 2018a, 2018b; Nagy \& Babic 2019; Nagy et al. 2019; Nagy et al. 2020a; Nagy et al. 2020b).

Knowing that the number of participating players during SSGs could affect the physiological responses, time motion characteristics and game performance, soccer coaches need to consider the aim of the training session during the microcycle. Thus, the main goal of the present study was to compare the effects of 3 different forms of SSG with various number of players. These 3 forms of SSGs are indeed very popular and often used by soccer coaches during training sessions. The findings could potentially provide valuable and reliable information to the coaching staff for the design of different forms of SSGs as part of their training units.

\section{Methods}

\section{Experimental approach to the problem}

In our research we measured internal load (cardiovascular response - HR values), external load (time-motion characteristics), individual game performance (game activity) and rate of perceived exertion (RPE) during three forms of SSGs with small (3 vs. 3), medium (6 vs, 6) and large (9 vs. 9) number of players.

\section{Participants}

The research group consisted of male youth soccer players $(n=18)$ (aged $16.5 \pm 0.71$ years, $\mathrm{VO}_{2 \max } 56.06 \pm 2.84 \mathrm{ml} . \mathrm{min}^{-1} \cdot \mathrm{kg}^{-1}$, maximum heart rate $\left[\mathrm{HR}_{\max }\right] 196.42 \pm 5.31$ beats.min ${ }^{-}$ $\left.{ }^{1}\right)$ from the FC DAC 1904 Dunajská Streda U17 soccer club.

According to the maximal heart rate $\left(\mathrm{HR}_{\max }\right)$ we determined 5 load zones. These zones were determined on the basis of level of intensities, which were defined by percentages of the $\mathrm{HR}_{\max }$ values. One of the main methods to acquire the data used during this research was heart rate (HR) measurement. First of all, we ascertain the values of maximal heart rate $\left(\mathrm{HR}_{\max }\right)$. To measure the HR the set of sports testers POLAR TEAM 2 PRO was used. The calculation of the percentage and time representation of HR values was done by using a special program and software POLAR TEAM 2. All soccer players were members of the same youth team competing in the top-level competition of this age group in Slovakia. Training frequency of the youth squad was seven training sessions a week and one soccer match. Before the research 
process the head coach divided the players into 2 well-balanced teams according to the player's performance-related level and playing position. Both teams included defenders, midfielders and forward players. During the SSGs the goalkeepers did not have the sports tester fastened to their chest, since we did not monitor the level of their HR values.

\section{Small-sided games}

We measured the HR values, time-motion characteristics, game performance and RPE scores during 3 forms of SSG with different number of players but with fixed rules. The SSGs were played on artificial turf, relative grid area for 1 player was $75 \mathrm{~m}^{2}$ in each SSG variants and was marked out with cones. On the pitch was placed standard goal (sized $7.32 \times 2.44 \mathrm{~m}$ ) at the centre of each goal line. For scoring in all formats of SSGs, all players had to be in the attacking half. All SSGs were played with unlimited touches of the ball and without offside rule. Replacement balls were immediately accessible along the entire pitch if the ball was kicked out of play. During SSGs were prepared 9 balls, 6 of them spread around the field, 2 of them were in goals and with one of them played the players soccer. The spare balls were also there in case if the ball would leave the playing field, the game could continue with another one. In this way, we tried to ensure the continuity of the game and to maintain the load intensity of the players. There was a minimum of coaches' encouragement during the SSG, but players could verbally encourage each other with the aim to maintain the intensity of SSG. During the SSGs the clear load time was 12 minutes.

Table 1

SSGs characteristics

\begin{tabular}{|c|c|c|c|c|c|c|c|c|c|c|c|}
\hline \multirow{2}{*}{ SSGs } & \multirow{2}{*}{$\begin{array}{l}\text { Players } \\
(n=18)\end{array}$} & \multirow{2}{*}{$\begin{array}{l}\text { GK } \\
(n=2)\end{array}$} & \multicolumn{2}{|c|}{ Field dimensions } & \multirow{2}{*}{$\begin{array}{l}\text { Field area } \\
{\left[\mathrm{m}^{2}\right]}\end{array}$} & \multirow{2}{*}{$\begin{array}{l}\begin{array}{l}\text { Area/ } \\
\text { player }\end{array} \\
{\left[\mathrm{m}^{2}\right]}\end{array}$} & \multicolumn{5}{|c|}{ Batch load } \\
\hline & & & $\begin{array}{l}\text { Width } \\
{[\mathrm{m}]}\end{array}$ & $\begin{array}{l}\text { Length } \\
{[\mathrm{m}]}\end{array}$ & & & $\begin{array}{l}\text { LI } \\
{[\mathrm{min} .]}\end{array}$ & $\begin{array}{l}\text { RS } \\
\text { [min.] }\end{array}$ & NR & NS & CL [min.] \\
\hline SSG1 & 3 vs. 3 & $1 / 1$ & 18 & 25 & 450 & 75 & 2 & 1 & 6 & 1 & 12 \\
\hline SSG2 & 6 vs. 6 & $1 / 1$ & 26 & 35 & 910 & 75 & 4 & 2 & 3 & 1 & 12 \\
\hline SSG3 & 9 vs. 9 & $1 / 1$ & 34 & 40 & 1360 & 75 & 6 & 3 & 2 & 1 & 12 \\
\hline
\end{tabular}

\section{Cardiovascular response}

One of the main methods to acquire the data used during this research was heart rate (HR) measurement. HRs were measured and stored by means of a heart rate monitor Polar Team 2 PRO(Polar Electro Oy, Kempele, Finland). The system recorded the heart rate into the interface with an immediate transfer of $5 \mathrm{~Hz}$ at one-second intervals, with a measurement error of 5 beats. Exercise intensity was expressed as $\% \mathrm{HR}_{\max }$ measured during the field test by Hipp (2014). Finally, exercise intensity was divided into 5 defined intensity zones: $50-59 \% \mathrm{HR}_{\max }-$ 
very low intensity, $60-69 \% \mathrm{HR}_{\max }$ - low intensity, 70-79\% $\mathrm{HR}_{\max }-$ medium intensity, $80-89 \%$ $\mathrm{HR}_{\max }$

- submaximal intensity, 90-100\% $\mathrm{HR}_{\max }$ - maximal intensity (Moravec et al. 2007). After the SSGs' the calculation of the time representation of HR values was done using a special program and software. The data were downloaded to a PC afterwards.

\section{Time-motion characteristics}

During the different forms of SSGs Polar Team 2 PRO sport testers (Polar Electro Oy, Kempele, Finland) were firmly fastened to the participants' under the chest to record external load data with frequency of $5.0 \mathrm{GHz}$. GPS data were analysed to identify the total distance covered (TDC), high intensity running (HIR) distance, number of accelerations (A) and decelerations (D) during different variants of SSG.

\section{Individual game performance}

Players' individual game performance was assessed by the Team Sports Assessment Procedure (TSAP), which is described in detail by Gréhaigne et al. (2005). The instrument reflects both technical and tactical aspects of game play by using macro-indicators related to successful game-play. Briefly, 6 technical-tactical actions were quantified for each player throughout the SSGs:

$\mathrm{CB}$ - conquered ball - (CB, e.g., the player intercepted or stole the ball from an opponent or recaptured it after an unsuccessful shot)

$\mathrm{RB}$ - received ball - (RB, e.g., the player received the ball from a teammate and did not immediately lose control of the ball)

LB - lost ball - (LB, e.g., player lost control of the ball)

$\mathrm{NB}$ - neutral ball - (NB, e.g., it is a routine pass to a teammate that does not put pressure on the opponent's team)

$\mathrm{P}$ - pass - (P e.g., complete the pass to teammate that contributes to the displacement of the ball towards the opponent team's defensive region)

SS - successful shot on goals (SS, e.g., it is considered successful when it scores or ensures the possession of the ball).

$\mathrm{VP}-$ volume of play $-\mathrm{CB}+\mathrm{RB}-$ it is the frequency of ball possession during SSGs.

$\mathrm{AB}-$ attacks with the ball $-\mathrm{P}+\mathrm{SS}-$ it is the frequency of passes and successful shots, or in this case the way to score for each SSGs.

$\mathrm{EI}-$ efficiency index $-\mathrm{AB} / 10+\mathrm{LB}$ - here $\mathrm{AB}$ indicates attacks with ball and LB indicates the balls lost. 
PS - performance score - (VP/2) + (EI x 10) - using VP volume of play and EI efficiency index.

Video recordings by Spiideo camera system were used which cover the entire playing field to record and after that retrospectively quantify the number of selected actions and individual game performance respectively. Indices were computed for each SSGs based on the players' performance.

$R P E$ - We got feedback from players by RPE scores of the previous exercise bout on a 15-point scale, ranging from 6-no exertional at all to 20-maximal exertion (Borg 1988).

\section{Statistical analysis}

The one-way ANOVA and Bonferroni post hoc test were used to determine the statistical significance of HR, time-motion characteristics, game performance and RPE. The level of statistical significance was set at $5 \%$ level. The results were interpreted, compared and we also connections were found between them. On the basis of these data, we formulated conclusions and recommendations for the sport theory and training practice.

\section{Results}

The duration of SSGs was 18 minutes and the net load time of it was 12 minutes. The work and rest ratio (LI:RI) was 1:0.5. The cardiovascular response of players' organism to load during SSGs is stated by the values of heart rate (HR). Details of the physiological response are given in table 2. Briefly, SSG with small number of players (3 vs. 3) triggered the highest HR response with $168.00 \pm 8.48$ beats. $\mathrm{min}^{-1}$ on average. The HR was likely to decrease to 157.75 \pm 8.53 beats. $\mathrm{min}^{-1}$ during SSG2 when 6 players played against the same number of opponent team. We recorded the lowest average HR values of monitored players during SSG3 (large number of players) $153.82 \pm 10.48$ beats. $\mathrm{min}^{-1}$. The difference between mean HR values was trivial between SSG1 and SSG2 among SSG2 and SSG3. We found statistically significant differences between SSG1 and SSG3 ( $T=3.1466 ; p<0.05)$.

\section{Table 2}

$H R$ values

\begin{tabular}{|c|c|c|c|c|c|c|}
\hline \multirow{2}{*}{ SSGs } & \multicolumn{2}{|l|}{$\mathbf{H R}_{\text {min }}$} & \multicolumn{2}{|l|}{$\mathbf{H R}_{\text {mean }}$} & \multicolumn{2}{|l|}{$\mathbf{H R}_{\max }$} \\
\hline & [beats.min $\left.{ }^{-1}\right]$ & SD & [beats.min $\left.{ }^{-1}\right]$ & SD & [beats.min ${ }^{-1}$ ] & SD \\
\hline SSG1 & 104.66 & \pm 9.07 & 168.00 & \pm 8.48 & 190.83 & \pm 6.55 \\
\hline SSG2 & 103.63 & \pm 4.05 & 157.75 & \pm 8.53 & 188.16 & \pm 8.90 \\
\hline SSG3 & 102.15 & \pm 14.15 & 153.82 & \pm 10.48 & 187.75 & \pm 11.05 \\
\hline
\end{tabular}

The research situation represented an examination of different selected physiological 
load indicators. In this case, it concerned the HR of soccer players during various different forms of SSG. Game duration spent in different HR intensity zones is given in Table 3. With respect to the proportion of the intensity zones, during SSG1 players spent the most time in maximal intensity zone 0:09:06 minutes of SSG duration. The longest time spent in the zone of submaximal intensity was throughout SSG2, 0:05:49 minutes.

Table 3

Time spent in different intensity zones during SSGs

\begin{tabular}{|c|c|c|c|c|c|}
\hline Intensity zones & $\begin{array}{l}50-59 \% \\
\text { of } H R_{\max }\end{array}$ & $\begin{array}{l}60-69 \% \\
\text { of } H R_{\max }\end{array}$ & $\begin{array}{l}70-79 \% \\
\text { of } H R_{\max }\end{array}$ & $\begin{array}{l}80-89 \% \\
\text { of } H R_{\max }\end{array}$ & $\begin{array}{l}90-100 \% \\
\text { of } H_{R_{\max }}\end{array}$ \\
\hline Intensity & Very low & Low & Medium & Submaximal & Maximal \\
\hline Time & [min.] & [min.] & [min.] & [min.] & [min.] \\
\hline SSG1 & 0:00:09 & $0: 00: 49$ & $0: 03: 13$ & $0: 04: 31$ & 0:09:06 \\
\hline SSG2 & 0:00:19 & $0: 01: 48$ & $0: 04: 36$ & $0: 05: 49$ & $0: 05: 18$ \\
\hline SSG3 & $0: 00: 49$ & 0:03:01 & $0: 03: 30$ & $0: 05: 15$ & $0: 04: 26$ \\
\hline
\end{tabular}

The highest intensity was ascertained during SSG with small number of players (3 vs. 3). This form of SSGs was the most demanding for the players' cardiovascular system.

Details of the time-motion characteristics are given in table 4 . We can see that the external load is closely related to internal responses in SSGs with different number of players.

Table 4

Time-motion characteristics during SSGs

\begin{tabular}{|c|c|c|c|c|c|c|c|c|}
\hline \multirow{2}{*}{ SSGs } & \multicolumn{2}{|l|}{ TDC } & \multicolumn{2}{|l|}{ HIR } & \multicolumn{2}{|l|}{$\mathbf{A}$} & \multicolumn{2}{|l|}{ D } \\
\hline & {$[\mathrm{m}]$} & SD & {$[\mathrm{m}]$} & SD & {$[\mathrm{n}]$} & SD & [n] & SD \\
\hline SSG1 & 1617.00 & \pm 69.18 & 40.16 & \pm 19.61 & 6 & \pm 2 & 4 & \pm 2 \\
\hline SSG2 & 1491.66 & \pm 121.87 & 35.16 & \pm 19.31 & 3 & \pm 2 & 2 & \pm 2 \\
\hline SSG3 & 1586.68 & \pm 160.97 & 92.52 & \pm 38.57 & 4 & \pm 2 & 3 & \pm 2 \\
\hline
\end{tabular}

The most total distance was covered during SSG1 $1617.00 \pm 69.18$ meters, the most high-intensive running distance was recorded during SSG3 92.52 \pm 38.57 meters, the most number of accelerations and decelerations we counted in SSG1. With respect to the overall distance covered, the distance moved in high intensity, the number of accelerations and decelerations, the differences between the SSGs were irrelevant.

Table 5

Individual game performance

\begin{tabular}{|c|c|c|c|}
\hline IGP & $S S G 1$ & $S S G 2$ & $S S G 3$ \\
\hline VP & 128 & 154 & 116 \\
\hline AB & 42 & 53 & 23 \\
\hline
\end{tabular}




\begin{tabular}{|l|l|l|l|}
\hline EI & 1.75 & 1.39 & 0.51 \\
\hline PS & 81.5 & 90.9 & 63.1 \\
\hline
\end{tabular}

Individual game performance was measured after the SSGs. The highest volume of play was recorded in SSG2 where 6 players played against each other and 6 neutral players tried to help them successfully solve complex game situations, 154 . The highest number of passes with adding pressure on the opponents' goal we counted after SSG2. Efficiency index was the highest in SSG2. In this case we found the highest performance score with 90.9 during SSG2, too. No noteworthy differences were found in RPE, ranging from 15.8 \pm 1.1 after SSG3 to 17.1 \pm 1.3 after SSG1.

Table 6

RPE scores

\begin{tabular}{|l|l|l|l|}
\hline SSGs & SSG1 & SSG2 & SSG3 \\
\hline RPE points & $17.1 \pm 1.3$ & $16.4 \pm 1.6$ & $15.8 \pm 1.1$ \\
\hline
\end{tabular}

\section{Discussion}

The purpose of the present research was to compare the cardiovascular response, timemotion characteristics, individual game performance and rate of perceived exertion during 3 different forms of SSG. Thus, 3 SSG variants with different number of players (3 vs. 3, 6 vs. 6, 9 vs. 9), but with same relative pitch area for 1 player was $75 \mathrm{~m}^{2}$, work and rest ratio (1:0.5), unchanged rules were compared. Although the head coach provided only mild feedback and verbal instructions, players tried to encourage each other verbally with the aim to maintain the intensity of SSG. The HR response during SSG1 (3 versus 3) was on the same level as in competitive matches in different youth categories (Florida-James \& Relly 1995; Helgerud 2001; Thatcher \& Batterham 2004; Rodrigues et al. 2007; Castagna et al. 2009).

Table 7

Mean HR values in soccer matches

\begin{tabular}{|c|c|c|c|}
\hline AUTHOR & HR mean $\left._{\text {[beats.min }}{ }^{-1}\right]$ & LEVEL & COUNTRY \\
\hline $\begin{array}{c}\text { Florida-James } \\
\text { \& Reilly (1995) }\end{array}$ & 165 & University competition & United Kingdom \\
\hline $\begin{array}{c}\text { Helgerud } \\
(2001)\end{array}$ & 171 & Junior competiton & Denmark \\
\hline $\begin{array}{c}\text { Thatcher } \\
\text { \& Batterham (2004) }\end{array}$ & 166 & Professional competition U20 & United Kingdom \\
\hline $\begin{array}{c}\text { Rodrigues et al. (2007) } \\
\text { Castagna et al. } \\
(2009)\end{array}$ & 166 & $\begin{array}{c}\text { Elit competiton } \\
\text { U17 }\end{array}$ & Brazil \\
\hline \begin{tabular}{c} 
Cit \\
\hline
\end{tabular} & 170 & U15 & Italy \\
\hline
\end{tabular}


According to Peráček (2014) the training process must stimulate the energy systems which prevail during soccer matches. In systematic training process this criterion is replaced by the cognition and adequate manipulation with variables of SSGs where we include the number of participating players, too. With respect to the proportion of time spent in various intensity zones, our data suggests that the cardiovascular response was the highest in SSG1, lower during SSG2 and less in SSG3. In SSG1 maybe the presence of small number of players played an important role because players should the entire time move to different spaces on the training field to create free space for themselves and help their teammates solve game situations adequately. Thus, we recommend SSG1 if the aim of the training session is to improve the load in maximal intensity zone. It can help the players to increase the level of their soccer specific endurance and game preparedness. During SSG1 players spent the most time in the maximum intensity zone 0:09:06 minutes, of SSG duration, which are very important from the view of soccer match and a systematic training process, in terms of load intensification.

Clemente et al. (2014) stated that SSGs that involve fewer players (3 vs. 3 a side forms of SSGs) could be used for high intensity soccer specific aerobic endurance training. If coaches want higher \% of $\mathrm{HR}_{\max }$ responses and players' time spent in high intensity zones, they should organize 3 vs. 3 SSGs. Heart rate is a generally accepted and often used physiological indicator of the players' physical activity in training units (Holienka 2016; Holienka \& Cihová 2016). The current results showed that SSG1 induced higher HR values than SSG2 and SSG3.

The highest intensity was ascertained during SSG1, in this conditions players spent the most time in the maximal intensity zone and above an anaerobic threshold. For players' cardiovascular system this variation was the most intensive. Little (2009) stated that SSGs that involve more players, such SSG2 (6 vs. 6) can be used to develop the anaerobic threshold, whereas SSG1 (3 vs. 3) might be used with the aim of enhancing maximum oxygen consumption. The calculation of the total distance covered, high-intensive running distance, the number of accelerations and decelerations during SSGs with different number of players provided information about the physical efforts performed during each SSG.

Clemente et al. (2016) found out, that 3-a-side SSG provide players with the opportunity to spend sufficient time in high intensity zones, while 9-a-side SSG format provide players with the opportunity to spend sufficient time in low intensity zones, which are specific to match demands. We can say that the external load is closely related to internal responses in the different forms of SSGs. In SSG1 players need to move all the time if they want to create free spaces for themselves or for their teammates. How they worked in space with the space 
provided us with results, that the most total distance covered was $1617.00 \pm 69.18$ metres, the most high-intensive running distance was achieved in SSG3 92.52 \pm 38.57 metres, most number of accelerations and decelerations we counted during SSG1. Individual game performance is very important when we try to educate young soccer players. Our study findings are comparable with most technical analyses in soccer SSGs that observed a higher number of individual indicators of technical-tactical actions in smaller formats of SSGs (Capranica et al. 2001; Katis $\&$ Kellis 2009). Considering the effects of different number of players, volume of play, attacks with the ball, efficiency index and performance score were the highest in SSG2 (6 vs. $6+6$ neutral players). Thus, a higher cardiovascular response suggests a pronounced participation in actions on the ball as only technical-tactical actions linked to winning or receiving the ball are summarized in VP. PS was most pronounced in SSG2, compared to SSG1 and SSG3. The individual game performance measure correlate positively with the proportion of the time spent above ANT, there is no evidence that the intensity of the investigated SSGs negatively affects the individual game performance as expressed by the TSAP.

Christopher et al. (2016) claims that the training of soccer players should take into account the specific technical, tactical and physiological requirements of the individual game performance, too. As a result, the SSG has become a favourite way in order to increase the level of physical preparedness that imitates the conditions that a player may encounter during the competitive match. During SSGs soccer players need to solve a lot of complex game situations. Evaluation of different game situations, choosing the right tactic option and implementation of individual game action is a sensomotoric activity. Soccer players need to be adequately cognitively prepared for the match and always try to solve the tasks during the game in a tactically and technically correct way. When we analyse individual game activity we need to consider these elements, too. The RPE scores ranging from $15.8 \pm 1.1$ after SSG3 to $17.1 \pm 1.3$ after SSG1. In contrast, previous studies that focused on rule changes (Brandes et al. 2017; Halouani et al. 2017) found statistically significant effects on RPE scores during different variants of SSGs. The discrepancy between the present results and those mentioned above could be due to the subjectivity of this measurement tool and the players' inexperience with this method. Indeed, the RPE is defined as a subjective measure of work intensity (Coquart et al. 2009) which may also be strongly affected by motivational or emotional factors.

In this study, we tried to find out more about the cardiovascular response, time-motion characteristics, individual game performance and RPE in 3 variants of SSG with different number of players. The results of this study suggest that SSG1 could be used for high intensity 
soccer specific aerobic endurance training, SSG2 is optimal for moderate intensity soccer specific endurance training and finally, SSG3 may be used for low intensity aerobic training by soccer coaches.

\section{Conclusions}

Soccer is developing and advancing unusually fast. It puts higher demands on the whole coaching staff and the entire training process and practice. Purposeful planning, appropriate management and innovative approaches in everyday training sessions are only small steps, things that lead every ambitious soccer coach to the right path of success. The use of modern technologies during training units, for example sport testers, GPS allows sport experts to identify the internal response of players organism and receive objective feedback on the adequacy of the training load.

After the rehabilitation process the medical staff and strength and conditioning experts need to be very careful with them after the injury. In the early process of the team training on the field we need them monitor the players' physical activity through GPS and in some cases change the training load. Soccer coaches need to be clear with the player and explain that this is precaution and not punishment.

Nonetheless, the present study proves that small-sided and conditioned soccer games can change players' individual performance, even in technical and tactical actions. From the obtained data it is possible to state that during SSGs with different number of players the HR values, time-motion characteristics, individual game performance, RPE scores were in different range. The most intense was in SSG1. During SSG1 players achieved the highest HR values, spent the most time in maximal intensity zone, in this case we recorded the biggest time-motion characteristics and the highest score of RPE.

Our recommendation is to integrate SSGs into the purposeful training process with different number of players to enhance players' technical ability, tactical decision-making skills, physical preparedness and mental resistance too. The reason for using above mentioned SSGs is that these situations place demands on the cardiovascular and movement system of the players that are similar to the competitive match conditions. Optimization, individualization and intensification the training load are very important in the systematic training process, there coaches should include SSGs with different number of players in the training process according to the aim of the day of the microcycle periodization and loading.

\section{Acknowledgments}


This study was supported by the Scientific Grant Agency of the Ministry of Education, Science, Research and Sport of the Slovak Republic and the Slovak Academy of Sciences (No. 1/0089/20): Assessment of sensory and motor component of movement skills in athletic training and rehabilitation.

\section{References}

1. ASCI, A., 2016. Heart rate responses during small sided games and official match-play in soccer. In: Sports. 4(2), 1-7. ISSN 2075-4663.

2. BORG, G. A., 1982. Psychophysical bases of perceived exertion. In: Medicine and Science in Sport and Exercise. 14(5), 377-381. ISSN 0195-9131.

3. BRANDES, M., L. MÜLLER a A. HEITMANN, 2017. Physiological responses, timemotion characteristics and game performance in 4 vs. 4 small-sided games in elite youth soccer players: Different number of mini-goals vs. stop-ball. In: Science and Medicine in Football. 1(2), 126-131. ISSN 2473-3938.

4. CAPRANICA, L., 2001. Heart rate and match analysis in pre-pubescent soccer players. In: Journal of Sports Sciences. 19(6), 379-384. ISSN 0264-0414.

5. CASTAGNA, C., F. IMPELlizZERI, E. CECCHINI, E. RAMPININI a J.C.B. ALVAREZ, 2009. Effects of intermittent-endurance fitness on match performance in young male soccer players. In: Journal of Strength and Conditioning Research. 23(7), 1954-1959. ISSN 1064-8011.

6. CLEMENTE, F. et al., 2012. The usefulness of small-sided games on soccer training. In: Journal of Physical Education and Sport. 12(1), 93-102. ISSN 2247-8051.

7. CLEMENTE, F. M., D. P. WONG, F. M.L. MARTINS a R. S. MENDES, 2014. Acute effects of the number of players and scoring method on physiological, physical, and technical performance in small-sided soccer games. In: Research in Sports Medicine. 22(4), 380-397. ISSN 1543-8627.

8. COQUART, J. B., R. LEGRAND, S. ROBIN, A. DUHAMEL, R. MATRAN a M. GARCIN, 2009. Influence of successive bouts of fatiguing exercise on perceptual and physiological markers during an incremental exercise test. In: Psychophysiology. 46, 209216. ISSN 1469-8986.

9. DELlal, A., C. LAGO-PENAS, D. P. WONG a K. CHAMARI, 2011. Effect of the number of ball contacts within bouts of 4 vs. 4 small-sided soccer games. In: International Journal of Sports Physiology and Performance. 6(3), 322-333. ISSN 1555-0265. 
10. FLORIDA-JAMES, G. a T. REILLY, 1995. The physiological demands of Gaelic football. In: British Journal of Sports Medicine. 29(1), 41-45. ISSN 0306-3674.

11. GRÉHAIGNE, J.F., J.F. RICHARD a L.L. GRIFFIN, 2005. Teaching and Learning Team Sports and Games. New York, NY: Routledge Falmer.

12. HALOUANI, J., H. CHTOUROU, A. DELLAL, A. CHAOUACHI a K. CHAMARI, 2017. Soccer small-sided games in young players: Rule modification to induce higher physiological responses. In: Biology of Sport. 34(2), 163-168. ISSN 0860-021X.

13. HILL-HAAS, S. V., B. T. DAWSON, F. M. IMPELliZZERI a A. J. COUTTS, 2011. Physiology of small-sided games training in football. In: Sports Medicine. 41(3), 199-220. ISSN 0112-1642.

14. HIPP, M., 2014. Futbal: Rozvoj vybraných pohybových schopností: Skúsenosti z praxe. 2. vydanie. Nitra: For Press. ISBN 978-80-10-01146-9.

15. HELGERUD, J., 2001. Aerobic endurance training improves soccer performance. In: Medicine and Science in Sports and Exercise. 33(11), 1925-1931. ISSN 0195-9131.

16. HOLIENKA, M., 1998. Tréningové zat'aženie a interval odpočinku, základné kategórie herného tréningu vo futbale. In: Acta Facultatis Educationis Physicae Universitatis Comenianae, 39. Bratislava: Univerzita Komenského, pp. 147-150. ISBN 80-223-1367-X.

17. HOLIENKA, M., 2016. Internal load of soccer players during preparatory games with a medium number of players. In: Journal of Physical Education and Sport. 16(2), 546-550. ISSN 2247-8051.

18. HOLIENKA, M. a I. CIHOVÁ, 2016. Vnútorné zat’aženie hráčov vo futbale v prípravných hrách so stredným počtom hráčov. In: Monitorovanie a regulovanie adaptačného efektu $v$ rozličných obdobiach prípravy vrcholových športovcov a talentovanej mládeže. Bratislava: ICM Agency, pp. 132-139. ISBN 978-80-89257-74-4.

19. CHRISTOPHER, J., M. BEATO a A. T. HULTON, 2016. Manipulation of exercise to rest ratio within set duration on physical and technical outcomes during small-sided games in elite youth soccer players. In: Human Movement Science. 48(August), 1-6. ISSN 01679457.

20. KAČÁNI, L., 2004. Futbal: Tréning hrou. Bratislava, SK: Peter Mačura - PEEM.

21. KATIS, A. a E. KELLIS, 2009. Effects of small-sided games on physical conditioning and performance in young soccer players. In: Journal of Sport Science and Medicine. 8(3), 374380. ISSN 1303-2968.

22. KÖKLÜ, Y., M. ALBAYRAK, H. KEYSAN, U. ALEMDAROGLU a A- DELLAL, 2013. Improvement of the physical conditioning of young soccer players by playing small-sided 
games on different pitch size - Special reference to physiological responses. In: Kinesiology. 45(1), 41-47. ISSN 1311-1441.

23. LITTLE, T., 2009. Optimizing the use of soccer drills for physiological development. In: Strength and Conditioning Journal. 31(3), 67-74.

24. MIKULIČ, M., P. PERÁČEK a M. BABIC, 2018. Vplyv prípravných hier na herný výkon elitných mládežníckych hráčov vo futbale. [Impact of small-sided games on the game performance of elite youth soccer players]. In: Zbornik vedeckých prác Katedry športových hier FTVŠ UK č. 25. Bratislava: Slovenská vedecká spoločnost' pre telesnú výchovu a šport, pp. 116-133. ISBN 978-80-89075-75-1.

25. MORAVEC, R. et al., 2007. Teória a didaktika výkonnostného a vrcholového športu. Bratislava: Fakulta telesnej výchovy a športu Univerzity Komenského. ISBN 978-8089075-31-7.

26. NAGY, N. a M. HOLIENKA, 2018. Intenzita tréningového zat’aženia v rôznych formách prípravných hier vo futbale. [Intensity of the training load in various forms of preparatory games in football]. In: Telesná výchova \& šport. 28(2), 24-29. ISSN 1335-2245.

27. NAGY, N. a M. BABIC, 2019. Intenzita tréningového zat’aženia futbalistov v prípravných hrách s rôznymi vel'kost'ami hracej plochy. [Intensity of soccer players' training load in small-sided games with various playing field sizes]. In: Scientia Movens 2019. Praha: Fakulta tělesné výchovy a sportu, pp. 310-325. ISBN 978 80-87647-48-6.

28. NAGY, N., M. HOLIENKA, M. BABIC, J. MICHÁLEK a E. KUNZMANN, 2019. Intensity of soccer players' training load in small-sided games with various content focus. In: Acta Facultatis Educationis Physicae Universitatis Comenianae. 59(1), 44-68. ISSN 2585-8777.

29. NAGY, N., M. HOLIENKA a M. BABIC, 2020a. Intensity of training load in various forms of small-sided games in soccer. In: Journal of Physical Education and Sport. 20(1), 53-62. ISSN 2247-8051.

30. NAGY, N., M. HOLIENKA, M. BABIC, J. MICHÁLEK a E. KUNZMANN, 2020 b. Intensity of soccer players' training load in small-sided games with different number of players. In: Acta Facultatis Educationis Physicae Universitatis Comenianae. 60(1), 55-74. ISSN 2585-8777.

31. OWEN, A. L., C. TWIST a P. FORD, 2004. Small-sided games: The physiological and technical effect of altering pitch size and player numbers. In: Insight. 7(2), 50-53. ISSN 1060-135X. 
32. PERÁČEK, P., 2014. Evidencia a kontrola intenzity tréningového zat’aženia futbalistov. Telesná výchova \& šport. 24(2), 2-6. ISSN 1335-2245.

33. PERÁČEK, P., M. BÔŽIK a M. MIKULIČ, 2018a. Internal load of elite Malaysian young soccer players in small sided games with different parameters. In: Acta Facultatis Educationis Physicae Universitatis Comenianae. 58(1), 32-43. ISSN 0520-7371.

34. PERÁČEK, P., M. BÔŽIK a M. MIKULIČ, 2018b. Vybrané charakteristiky vnútorného zat’aženia elitných mladých futbalistov $\mathrm{v}$ prípravných hrách s rôznymi parametrami. [Internal load of youth elite soccer players in various small-sided games]. In: Studia Sportiva. 12(2), 79-86. ISSN 2570-8783.

35. RAMPININI, E., et al., 2007. Factors influencing physiological responses to small-sided soccer games. In: Journal of Sports Sciences. 25(6), 659-666. ISSN 0264-0414.

36. RODRIGUES, V., L. MORTIMER, L. CONDESSA, D. B. COELHO, D. SOARES a E. GARCIA, 2007. Exercise intensity in training sessions and official games in soccer. In: Journal of Sport Science and Medicine. 6(Suppl. 10), 57-61. ISSN 1303-2968.

37. THATCHER, R., a A. M. BATTERHAM, 2004. Development and validation of a sportspecific exercise protocol for elite youth soccer players. In: Journal of Sports Medicine and Physical Fitness. 44(1), 15-22. ISSN 0022-4707. 